腹床応用上は闑題がなかった：又， ${ }^{201} \mathrm{TlCl}$ は甲状腺腫を 有する亚者の甲状腺に，より多く集積するととを認めた が，乙れらの疾㭧での甲状腺吸収線量は，0.007 0.729 $\mathrm{rads} / \mathrm{mCi}$ の䇶网を示し，多くの症例では無視しうる程 度であった。一方, ${ }^{201} \mathrm{TICl} を,{ }^{131} \mathrm{CsCl}$ p ${ }^{99 \mathrm{~m}} \mathrm{Tc}-\mathrm{PYP}$. 実際の心筋 image で比較した結果，現在最すすぐれた 心筋スキャン用核種であることを確めた。

\section{RI 注腸法による門脈造影の検討}

大服大学医学部附属病院

中央放射線部 RI 検查室

○中村幸夫 ·久住佳三 大森英史・增田一孝

〔目的】 RI 注腸法による門脈造影検查は，大阪市立 大学病院等で，Tc-99m を用いて種々鵤みられているが， 今回我々は Xe-133 が脂溶性であり腸よりの吸取が良い と考えられるとと, 叉 $\mathrm{Kr}-81 \mathrm{~m}$ は連続注人が可能であ り，閒脈造影に適しているのではないか子考え，Tc-99m, $\mathrm{Xe}-133, \mathrm{Kr}-81 \mathrm{~m}$ の 3 核種を用い経值腸門脈造影を行な い，又経脾門脈造影と合わせて比較検討したので報告す る.

〔結論】 Xe-133での結直腸門脈造影では，明膫な.䦗 脈, 肝臓のイメージが描出されなかった. $\mathrm{Kr}-81 \mathrm{~m}$ につ いても同樣であった。しかし，Tc-99m では明瞭な門脈， 旰臟のイメージが得られた。

\section{3. ボルメトロンの使用経験}

\section{（従来からの循環血液量測定法と比較して）}

和歌山県立医科大学附属病院放射線科:

○鳥住和民·中村牧子・根来良典

ボルメトロンについて，2〜3の基礎的な実験を行なう

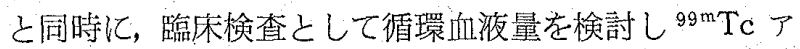
ルブミン（第一ラジオアイントープ研究所）を用いた徒 来の測定法と比較検討したので報告する。

[基礎的検討]

1. 注射器内容量による計数率の変化:

2. 各 RI 濃度における測定精度など

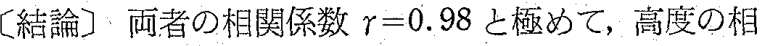
関関係を示した。ボルメトロン法は簡単で正確，かつ迅 速㳊測定できるが従来の方法に比へて，採血量の多いの が点と思われる。

4. 廃液シンチレーターの処理（第 2 報） 血中エストラジオールの測定後のシンチレーター再利用

和歌山県立医科大学附属病院放射線科 ○鳥住和民・中村牧子・根来良典
廃液シンチレーターの再利用及び廃液シンチレーター から活性炭による ${ }^{3} \mathrm{H}$-エストラジオールの国収・国収处 理後の廃液シンチレーターの再利用についての实験を行 なったので報告する。

[实験内容]

1. 処理及び再利用可能なシンチレーターの選択

2. 彷来使用シンチレーターとの測定感度比較

3. 活性炭量による回收率の変化

4. 回收処理後の廃液シンチレーターに加える $\mathrm{PPO}$, POPOP の混合比

5.・蹊床検查など

〔結論】再利用可能なシンチンーター（トルエン 200 $\mathrm{m} l$, トリトン-100 $100 \mathrm{ml}$, PPO $800 \mathrm{mg}$, POPOP $60 \mathrm{mg}$, を使用することにより廃液シンチレーターを約 $1 / 4$ 亿減 容させることができた。

\section{Radio immunoassay による血中 aldosterone} の測定法（第 4 報）

${ }^{125}$ I を用いた血中 aldosterone キットについて 和歌山県立医科大学附属病院放射線科 中村牧子・ ○鳥住和民・根来良典

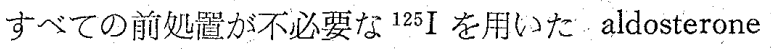
キット（ダイナボット社）の基礎的検討を行なったので 報告する。

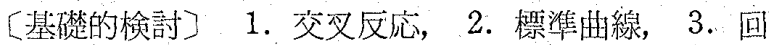
収率，4. 再現性，5．臨床応用，6. PRA とアルドス テロン値.

〔結論】”125I-aldosterone を用いた本キットは特異性 の高い抗体を用いており，試料の量も少なく，上り簡単 に，精度も高く，血漿 aldosterone 值を測定でき，かつ CIS キットとの相関係数が $r=0.963(n=57)$ と良い相 関孝示した. 又正常值は $4.48 \pm 2.4 \mathrm{ng} / \mathrm{d} l$ であった。

\section{座 長 集 約 $(\mathbf{1} \sim 5)$}

\section{金尾㤵在(住友病院)}

RI の 5 題につひて担当した，Tl-201(兵大，西川) の 混在核種について間題がないことはわれわれを安心させ てくれた。イメージング開始時間は多少早め (20〜30分) の方がよいのではないだろうか，RI 注腸法（庆大，中 村）は臨床応用成績から ${ }^{99 \mathrm{~m}} \mathrm{TcO}_{4}$ - が適当であるとの意 見はうなづける所であった. ボルメトロン（和大，鳥住） の有用性は自動的加つ簡便な計算処理にある. RISA と ${ }^{99 \mathrm{~m}} \mathrm{Tc}$-HSA の相関はよすぎるようでもある。シンチレ 一タ一再生（和大，鳥住）の工疒は好感のあてる真面目 な問題への取り組みがみられる。アルドステロン測定法 （和大，舄住）洁從来比比し格段飞すぐれた試泉の紹介 